\title{
The Malay Version of Patient Activation Measure: An Instrument for Measuring Patient Engagement in Healthcare
}

(Ukuran Pengaktifan Pesakit Versi Melayu: Alat untuk Mengukur Penglibatan Pesakit dalam Penjagaan Kesihatan)

\author{
SYAHNAZ MOHD HASHIM, IDAYU BADILla IDRIS*, SHALISAH SHARIP, RAFIDAH BAHARI \& NASRIN JAHAN
}

\begin{abstract}
Effective diabetes management depends on both pharmacological treatment and patients' engagement in their own care. PAM is an instrument that measures patients' ability to self-manage their chronic illnesses and determines patients' level of activation. The purpose of this study was to develop a translated Malay version of the PAM instrument and subsequently, to conduct a reliability and validity assessment. A cross-sectional study among patients with type 2 diabetes was performed in a teaching public primary care clinic. Forward and backward translation was conducted, followed by pre-testing and cognitive interviewing. Data from 130 patients were analysed using SPSS software to assess the internal consistency and the psychometric properties of the Malay version of PAM instrument. Cronbach's alpha for all items was 0.87, indicating good internal consistency. Exploratory Factor Analysis (EFA) showed a possibility of a three-factor model, which were labelled as a) confidence in performing preventive behaviors b) feel responsible and in charge of own health, and c) knowledge, ability to communicate and adherence to treatment. All items have a factor loading of higher than 0.4. The Cronbach's alpha value was 0.85, 0.7 and 0.58 for the first, second and third subscales, respectively. The Malay version of PAM instrument showed a good reliability index and might have multiple subscales. Assessing these subscales are useful for the healthcare team in the evaluation of 'patient activation' among patients with diabetes. Efforts will thus be easier when responding to the patients'needs and facilitating them to become active health managers.
\end{abstract}

Keywords: Malay; patient activation; patient engagement; reliability; validation

\section{ABSTRAK}

Pengurusan diabetes yang berkesan bergantung kepada kedua-dua rawatan farmakologi dan penglibatan pesakit dalam penjagaan kesihatan mereka. Ukuran Pengaktifan Pesakit (PAM) adalah satu instrumen yang mengukur keupayaan pesakit untuk mengurus kendiri penyakit kronik dan menentukan tahap pengaktifan pesakit. Tujuan kajian ini adalah untuk menghasilkan versi Bahasa Melayu bagi instrumen PAM dan untuk menjalankan penilaian kebolehpercayaan dan kesahihan. Kajian keratan rentas dalam kalangan pesakit diabetes telah dijalankan di sebuah klinik pengajaran awam penjagaan primer. Penterjemahan ke dalam Bahasa Melayu dan semula ke dalam Bahasa Inggeris telah dilakukan, diikuti dengan pra-ujian dan wawancara kognitif. Data daripada 130 pesakit dianalisis dengan perisian SPSS untuk menilai ketekalan dalaman dan ciri psikometrik bagi instrumen PAM versi Bahasa Melayu. Nilai Cronbach alpha untuk semua item adalah 0.87, menunjukkan konsistensi dalaman yang baik. Analisis faktor eksplorasi menunjukkan kemungkinan wujudnya tiga faktor model yang dilabelkan sebagai: a) keyakinan dalam melakukan amalan pencegahan b) berasa bertanggungjawab dan menjaga kesihatan diri dan c) pengetahuan, berkeupayaan untuk berkomunikasi dan pematuhan langkah rawatan. Seтua item mempunyai faktor pemuatan melebihi 0.4. Nilai Cronbach alpha adalah 0.85, 0.7 dan 0.58 untuk subskala pertama, kedua dan ketiga. Instrumen PAM versi Bahasa Melayu telah menunjukkan indeks kebolehpercayaan yang baik dan berkemungkinan mempunyai tiga subskala. Pengukuran subskala ini memanfaatkan pasukan penjagaan kesihatan untuk membuat penilaian aktivasi dalam kalangan pesakit diabetes. Usaha akan menjadi lebih mudah dalam menanggapi keperluan pesakit dan membantu mereka menjadi pengurus kesihatan yang aktif.

Kata kunci: Aktivasi pesakit; kebolehpercayaan; Melayu; pengesahan; penglibatan pesakit

\section{INTRODUCTION}

Chronic diseases are among the leading cause of morbidity and mortality worldwide and diabetes mellitus is one of the most debilitating diseases (WHO 2016, 2014).
Over the years, the number of patients with diabetes has increased, causing a substantial economic burden to this country (IPH 2015; Quek 2014). Despite the advances in pharmacological medicine, many patients fail to achieve 
optimal glycaemic control (Mafauzy et al. 2011). This problem has led to a growing concern among the healthcare providers to look into the critical component of diabetes management which is patients' engagement in their own care (ADA 2017; Chrvala et al. 2016; Holman \& Lorig 2004; Shrivastava et al. 2013). Patients' ability to engage in self-management contributes to the disease control as they need to monitor their blood sugar regularly, adhere to their medication and incorporate a healthy lifestyle into their daily routine (ADA 2017).

For patients to be engaged in their care, they should first believe that their role is important. They should acquire the knowledge, self-care skills and have the confidence to manage the disease. These characteristics are linked to a concept called 'patient activation' (Hibbard et al. 2004). Numerous evidence supports a positive relationship between patient activation and clinical outcomes, care satisfaction, as well as a reduction in healthcare costs (Greene et al. 2015; Hibbard \& Greene 2013; Mccabe et al. 2018; Shively et al. 2013). Improvements in the glycaemic, lipid and blood pressure control were demonstrated in patients who were activated compared to those who were not (Sacks et al. 2017; Shah et al. 2015). Given the importance of assessing patient activation in the healthcare setting, Hibbard et al. (2004) developed a scale, known as PAM. The shorter version of this scale consists of thirteen items, organised in hierarchical order (Hibbard et al. 2005). The score of all items is computed to derive the total score, which is then used to determine patients' level of activation (Hibbard et al. 2005). There are four levels of activation with the lowest being at level one, while the highest is level four, which indicates a patient's proficiency in self-management (Graffigna et al. 2015; Hibbard et al. 2005). Individuals who are highly engaged in their own care would show adequate capacity and confidence in managing their disease (Graffigna et al. 2015).

Earlier reports stated that approximately half of patients with diabetes were activated, suggesting that some patients have an adequate level of engagement (Bos-touwen et al. 2015; Remmers et al. 2009; Roberts et al. 2016; Zimbudzi et al. 2017). However, these findings were reported from studies in the West and the results may be different compared to the Asian population, as Asians have diverse views of health compared to the Western communities. For example, certain Asian societies believe that external factors such as fate or luck, determine the outcome of any illnesses (Lucas et al. 2013; Patel et al. 2015). Some are also more likely to let others (their family members or healthcare providers) decide their course of actions (Cheng et al. 2013; Yeoh et al. 2017), portraying an attitude of an external health locus of control (Lucas et al. 2013). This issue has received substantial interest from healthcare providers, as it may negatively affect patients' commitment and engagement in their healthcare (Perfetti 2018).

Since Malaysia is a multi-ethnic country consisting of Malay, Chinese, and Indian ethnicities, there is a valid concern that these problems could exist among its population. Hence, there is an urgent need to assess patients' engagement and activation in managing diabetes in this setting. Before a formal evaluation could be conducted, it is a prerequisite to have a valid measure of PAM in the Malay version, which is the national language. PAM scale has been translated into many languages and scholars have examined its reliability and psychometric properties. The results have been convincing, suggesting that this instrument is reliable and has good psychometric properties (Ahn et al. 2015; Graffigna et al. 2015; Moljord et al. 2015; Ngooi et al. 2017; Packer et al. 2015; Rademakers et al. 2012; Zill et al. 2013). Although earlier psychometric testing has showed that it is a unidimensional scale (Graffigna et al. 2015; Ngooi et al. 2017; Packer et al. 2015), recent development has indicated that it is possible to have more than one dimension (Cunha et al. 2018; Moljord et al. 2015; Schmaderer et al. 2015). This argument was also put forward because several results showed that the value of variance explained by one factor was not large, which was between 38 and $41 \%$ (Graffigna et al. 2015; Ngooi et al. 2017; Packer et al. 2015).

Although scholars have complimented PAM as a robust tool, it has yet to be tested among the Malaysian population. Therefore, the current study aimed to translate the PAM scale into Malay and conduct reliability as well as validity assessment. This study could help to determine whether the Malay version of PAM is suitable for the local setting and to examine its' underlying structure. This effort could benefit the healthcare providers in evaluating patient's engagement in diabetes care and the findings could serve as a basis for developing appropriate intervention programmes.

\section{MATERIALS AND METHODS}

\section{STUDY DESIGN AND PROCEDURES}

This cross-sectional study was conducted in a teaching public primary care clinic, Klinik Primer PPUKM in March 2019. A sample size of 130 was targeted as 10 participants were estimated for each item in the PAM scale. The rule of having 10 respondents to one item ratio followed the recommendation of sample size calculation for the questionnaire validation procedure (Costello \& Osborne 2005). Participants were recruited through convenient sampling, based on the following criteria: aged 18 years and above, able to read Malay, has a written diagnosis of type 2 diabetes, and has no visual or cognitive impairment. Informed consent was obtained from these patients before the questionnaire was distributed. The 
Malay version of the PAM scale was self-administered. Patients' sociodemographic and clinical profiles were also taken during this survey. Permission to use the PAM scale was attained before this study commenced.

\section{TRANSLATION AND ADAPTATION PROCESS}

The translation and adaptation process was done in several steps. After the content experts have reviewed the original questionnaire, a medical officer and a Malay linguistic expert performed the forward translation from English to Malay. Two translated Malay versions were produced and subsequently, these two were harmonised. Next, another medical officer and an English expert performed the backward translation to English. All four translators are proficient in both Malay and English languages. The two English versions were reviewed and compared with the original. Although several different words were used in the translated versions, the panel of experts (three family medicine specialists, a psychologist, a psychiatrist and a public health physician) was satisfied as the conceptual meaning was similar with the original questionnaire. They also agree to specify the word 'health condition' to 'diabetes' as this study intended to distribute the questionnaire among patients with diabetes.

The next step was pre-testing and cognitive debriefing to seven patients with type 2 diabetes with different educational backgrounds and ethnicities. These participants answered the Malay version of the PAM scale first prior to the individual debriefing session. The researcher went through every item with the participants and invited them to share their understanding of those items. A few words under items number $1,8,10$ and 13 were identified as ambiguous and needed more explanation. Subsequently, the outcome of the pre-testing and cognitive debriefing was discussed with the experts.

The experts agreed to make some modifications to the Malay version, in which a few words were added to these items to ensure that they are specific and clear. The phrase in item 1, "When all is said and done, I am the one who is responsible for managing my diabetes" was reworded to "In whatever circumstances, I am the one who is responsible". For item 8 , the word 'nature' was noted to be vague and the item was re-phrased to "I understand the nature and causes of my diabetes (nature refers to symptoms and complications)". A few words were added to item 10 to explain the meaning of 'lifestyle': "I have been able to maintain lifestyle changes (good eating habits and exercise) for my health that I have made". As for item 13, the phrase "the time of stress" was too broad and less understood. This statement was modified into "I am confident that I can maintain lifestyle changes like diet and exercise even during the time of stress (such as feeling unwell or tired)". This adaptation concurs with the original meaning of this item during the development of PAM (Hibbard et al. 2004). Later, the revised version was given to five more participants for feedback. They verified that the revised version was more precise and well-understood.

\section{DATA ANALYSIS}

The data were analysed using IBM SPSS software version 25. Descriptive statistics were conducted. The items' responses followed the original instrument, which are 'strongly disagree', 'disagree', 'agree', 'strongly agree' and 'not applicable'. The internal consistency was assessed before performing the EFA for construct validity. These data were examined for suitability for EFA by computing the Correlation Matrix, Kaiser-Meyer-Olkin (KMO) value and Bartlett's test of sphericity. Factors were extracted using Principal Component Analysis and factors with Eigenvalue of more than one were retained. The Varimax rotation method was chosen to determine the factor loading for each item.

\section{RESULTS}

\section{SOCIODEMOGRAPHIC AND CLINICAL CHARACTERISTICS OF THE PARTICIPANTS}

A total of 174 participants were recruited, but only 156 patients returned their questionnaire, giving a response rate of $89 \%$. Then, twelve questionnaires had to be excluded from the analysis because they were incomplete. Another eleven questionnaires with all 'agree' responses and three with all 'strongly agree' responses were excluded. This step was done to minimise the possibility of unreliable data based on the concern raised by the original author and it was similarly done by previous researchers (Insignia Health 2009; Laranjo et al. 2018; Packer et al. 2015; Rademakers et al. 2012). Hence, the final number for data analysis was 130. Table 1 shows the sociodemographic and clinical characteristics of the participants. The mean age of the participants was 61.23 years old (SD 8.49). Approximately three-quarters of the participants were Malay, 19.2\% were Chinese and 3.8\% were Indians. Nearly a quarter attained up to the primary level of education. The median duration of having diabetes was ten years (IQR 8) and insulin injection was one of the treatments for half of the participants.

\section{ITEM DESCRIPTIVE STATISTICS}

All items were scored as 'agree' by approximately 50\% of the participants. For the non-applicable' options, item number 9 scored the highest percentage, at $4.6 \%$, as shown in Table 2. Table 3 displays the floor percentage of between 0 and $3.1 \%$, with 5.4 to $26.9 \%$ for the ceiling percentage. 
TABLE 1. Sociodemographic and clinical characteristics of 130 participants

\begin{tabular}{|c|c|c|c|c|}
\hline & Variable $(\mathrm{N}=130)$ & Mean(SD) & Median (IQR) & n $(\%)$ \\
\hline Age & & $61.23(8.49)$ & & \\
\hline Age group & $18-39$ & & & $3(2.3)$ \\
\hline \multirow[t]{4}{*}{ (years old) } & $40-49$ & & & $7(5.4)$ \\
\hline & $50-59$ & & & $40(30.8)$ \\
\hline & $60-69$ & & & $59(45.4)$ \\
\hline & 70 and above & & & $21(16.2)$ \\
\hline \multirow[t]{2}{*}{ Gender } & Male & & & $61(46.9)$ \\
\hline & Female & & & $69(53.1)$ \\
\hline \multirow[t]{3}{*}{ Ethnic } & Malay & & & $100(76.9)$ \\
\hline & Chinese & & & $25(19.2)$ \\
\hline & Indian & & & $5(3.8)$ \\
\hline \multirow{3}{*}{$\begin{array}{l}\text { Marital } \\
\text { status }\end{array}$} & Single & & & $3(2.3)$ \\
\hline & Married & & & $107(82.3)$ \\
\hline & Divorced/Widowed & & & $20(15.4)$ \\
\hline \multirow[t]{6}{*}{ Education level } & No formal & & & $3(2.3)$ \\
\hline & Primary school & & & $27(20.8)$ \\
\hline & Secondary school & & & $74(56.9)$ \\
\hline & Diploma/Matriculation & & & $11(8.5)$ \\
\hline & Degree & & & $10(7.7)$ \\
\hline & Masters/PhD & & & $5(3.8)$ \\
\hline \multirow[t]{2}{*}{ Employment } & Yes & & & $49(37.7)$ \\
\hline & No & & & $81(62.3)$ \\
\hline \multirow{3}{*}{$\begin{array}{l}\text { Monthly } \\
\text { income }\end{array}$} & RM 3,000 or less & & & $93(71.5)$ \\
\hline & RM 3,001-6,300 & & & $32(24.6)$ \\
\hline & More than RM 6,300 & & & $5(3.8)$ \\
\hline & Duration of DM & & $10(8)$ & \\
\hline \multirow[t]{3}{*}{ Current medication } & Oral hypoglycaemic & & & $65(50.0)$ \\
\hline & Only Insulin & & & $9(6.9)$ \\
\hline & Both OHA \& Insulin & & & $56(43.1)$ \\
\hline \multirow{2}{*}{$\begin{array}{l}\text { Presence of co- } \\
\text { morbidity }\end{array}$} & Yes & & & $121(93.1)$ \\
\hline & No & & & $9(6.9)$ \\
\hline \multirow{5}{*}{$\begin{array}{l}\text { Number of co- } \\
\text { morbidity } \\
\text { (ies) }\end{array}$} & 0 & & & $9(6.9)$ \\
\hline & 1 & & & $59(45.4)$ \\
\hline & 2 & & & $45(34.6)$ \\
\hline & 3 & & & $13(10.0)$ \\
\hline & 4 & & & $4(3.1)$ \\
\hline
\end{tabular}

RM: Malaysian Ringgit (Currency of Malaysia), OHA: oral hypoglycaemic drugs 
TABLE 2. Distribution of item responses of the Malay version of PAM

\begin{tabular}{lccccc}
\hline Item & Strongly disagree & Disagree & Agree & $\begin{array}{c}\text { Strongly } \\
\text { agree } \\
\mathrm{n}(\%)\end{array}$ & $\mathrm{n}(\%)$ \\
\hline 1 & $\mathrm{n}(\%)$ & $\mathrm{n}(\%)$ & $\mathrm{n}(\%)$ & $32(24.6)$ & $0(0.0)$ \\
2 & $0(0.0)$ & $2(1.5)$ & $96(73.8)$ & $35(26.9)$ & $1(0.8)$ \\
3 & $1(0.8)$ & $1(0.8)$ & $92(70.8)$ & $22(16.9)$ & $1(0.8)$ \\
4 & $2(1.5)$ & $26(20.0)$ & $79(60.8)$ & $18(13.8)$ & $0(0.0)$ \\
5 & $4(3.1)$ & $27(20.8)$ & $81(62.3)$ & $24(18.5)$ & $0(0.0)$ \\
6 & $0(0.0)$ & $6(4.6)$ & $100(76.9)$ & $17(13.1)$ & $2(1.5)$ \\
7 & $0(0.0)$ & $5(3.8)$ & $106(81.5)$ & $22(16.9)$ & $0(0.0)$ \\
8 & $1(0.8)$ & $16(12.3)$ & $91(70.0)$ & $19(14.6)$ & $1(0.8)$ \\
9 & $2(1.5)$ & $18(13.8)$ & $90(69.2)$ & $7(5.4)$ & $6(4.6)$ \\
10 & $1(0.8)$ & $35(26.9)$ & $81(62.3)$ & $18(13.8)$ & $0(0.0)$ \\
11 & $1(0.8)$ & $37(28.5)$ & $74(56.9)$ & $13(10.0)$ & $1(0.8)$ \\
12 & $2(1.5)$ & $31(23.8)$ & $83(63.8)$ & $9(6.9)$ & $5(3.8)$ \\
\hline 3 & $3(2.3)$ & $43(33.1)$ & $70(53.8)$ & $9(6.9)$ & $0(0.0)$ \\
\hline
\end{tabular}

TABLE 3. Descriptive statistics and reliability analysis for all items of the Malay version

\begin{tabular}{lccccc}
\hline & Mean & SD & $\begin{array}{c}\text { Floor } \\
\%\end{array}$ & $\begin{array}{c}\text { Ceiling } \\
\%\end{array}$ & $\begin{array}{c}\text { Corrected item-total } \\
\text { correlation }\end{array}$ \\
\hline 1 & 3.23 & 0.46 & 0.0 & 24.6 & 0.45 \\
2 & 3.26 & 0.52 & 0.8 & 26.9 & 0.48 \\
3 & 2.95 & 0.68 & 1.5 & 16.9 & 0.69 \\
4 & 2.87 & 0.67 & 3.1 & 13.8 & 0.71 \\
5 & 3.14 & 0.46 & 0.0 & 18.5 & 0.61 \\
6 & 3.12 & 0.47 & 0.0 & 13.1 & 0.28 \\
7 & 3.03 & 0.57 & 0.8 & 16.9 & 0.49 \\
8 & 2.99 & 0.62 & 1.5 & 14.6 & 0.56 \\
9 & 2.86 & 0.72 & 0.8 & 5.4 & 0.42 \\
10 & 2.84 & 0.66 & 0.8 & 13.8 & 0.65 \\
11 & 2.85 & 0.64 & 1.5 & 10.0 & 0.68 \\
\hline 12 & 2.77 & 0.77 & 2.3 & 6.9 & 0.48 \\
\hline
\end{tabular}




\section{RELIABILITY ANALYSIS FOR TOTAL ITEMS}

Cronbach's alpha for the total items was 0.87 , indicating a good internal consistency (Tavakol \& Dennick 2011) as presented in Table 3. The inter-item correlations ranged from 0.05 to 0.67 , while the corrected item-total correlation ranged from 0.28 to 0.71 .

\section{CONSTRUCT VALIDITY}

The EFA and Scree plot supported the three-factor model. The KMO value was 0.86 and the p-value was $<0.0001$ for Bartlett's test of sphericity. Principal Component Analysis showed three factors accounted for $60 \%$ of the total variance with $41 \%$ from the first factor, and 11 and $8 \%$ from the second and third factors, respectively.
Table 4 shows the results of factor analysis. Items number $3,4,9,10,11,12$, and 13 were grouped into the first factor. These items describe the extent of selfconfidence in performing preventive actions, such as lifestyle changes, minimising complications and solving problems. Items number 1, 2, and 5 emerged as the second factor. This factor is related to a person's belief that he/she has to be responsible and takes charge of managing his/ her own health. The third factor consists of item number 6,7 , and 8 which reflects an individual's knowledge, and ability to communicate and adherence to treatment. All items have a factor loading of higher than 0.4 , which is meaningful (Hair et al. 2014). There was cross-loading for items number $3,5,8$, and 10 .

TABLE 4. EFA of items in the Malay version

\begin{tabular}{|c|c|c|c|}
\hline Items & Factor 1 & Factor 2 & Factor 3 \\
\hline 1 & & 0.83 & \\
\hline 2 & & 0.78 & \\
\hline 3 & 0.60 & 0.47 & \\
\hline 4 & 0.69 & & \\
\hline 5 & & 0.45 & 0.41 \\
\hline 6 & & & 0.73 \\
\hline 7 & & & 0.60 \\
\hline 8 & 0.40 & & 0.64 \\
\hline 9 & 0.56 & & \\
\hline 10 & 0.66 & & 0.40 \\
\hline 11 & 0.75 & & \\
\hline 12 & 0.74 & & \\
\hline 13 & 0.68 & & \\
\hline
\end{tabular}

KMO value is 0.86. Data extraction using Principal component and Varimax rotation.

Factor loading below 0.4 is suppressed for presentation

\section{RELIABILITY ANALYSIS FOR EACH SUBSCALE}

Since EFA yielded three factors, the reliability of each subscale was assessed. Cronbach's alpha for the first subscale was $0.85,0.70$ for the second and 0.58 for the third subscale. The corrected item correlation for items within each subscale ranged from 0.37 to 0.71 , as presented in Table 5. 
TABLE 5. Factor structure and reliability analysis for each subscale of the Malay version of PAM scale

\begin{tabular}{|c|c|c|c|c|}
\hline \multirow[t]{2}{*}{ Malay version of PAM scale } & \multicolumn{3}{|c|}{ Factor } & \multirow{2}{*}{$\begin{array}{l}\text { Corrected } \\
\text { item-total } \\
\text { correlation }\end{array}$} \\
\hline & 1 & 2 & 3 & \\
\hline
\end{tabular}

Subscale 1: Confidence in performing preventive actions to maintain health

3 I am confident that I can take actions that help prevent or minimize some 0.60 symptoms or problems associated with my diabetes

$4 \quad$ I know what each of my diabetes medications do

0.69

0.71

9 I know the different medical treatment options available for my diabetes

0.56

10 I have been able to maintain lifestyle changes (good eating habits and exercise) $\quad 0.66$ for my health, that I have made

11 I know how to prevent further problems with my diabetes

12 I am confident I can figure out solutions when new situations or problems arise with my health condition

13 I am confident that I can maintain lifestyle changes like diet and exercise even during the time of stress (feeling unwell or tired)

Subscale 2: Feel responsible and in charge of owns health

1 In whatever circumstances, I am the person who is responsible for managing my diabetes

2 Taking an active role in my own health care is the most important factor in

5 I am confident that I can tell when I need to get medical care and when I can handle a health problem myself

Subscale 3: Knowledge, ability to communicate and adherence to treatment

6 I am confident that I can tell my healthcare provider concerns I have, even when he or she does not ask

7 I am confident that I can follow through on medical treatments that I need to do at home

8 I understand the nature and causes of my diabetes (nature refers to symptoms and complications)

\section{DISCUSSION}

This study is a preliminary effort to assess the reliability and validity of the Malay version of PAM scale in a Malaysian setting. The translated Malay version maintains similar meaning with additional words in several items for clarity. Participants with all 'similar responses' were excluded to reduce the possibility of unreliable data and to ensure that the data were accurate, as well as trustworthy.
The current study adopted multiple approaches for validation which included content validation by experts, face validity by patients with diabetes and construct validation. The findings demonstrated that the Malay PAM scale is reliable with Cronbach's alpha of 0.87, replicating the findings from earlier studies (Graffigna et al. 2015; Ngooi et al. 2017; Packer et al. 2015). The results indicated that these items showed good consistency in measuring the concept of activation in patients with diabetes. 
Regarding the psychometric properties of the PAM scale, previous literature reported a different conclusion based on two methods. Studies using the Rasch method showed that PAM scale is unidimensional (Ahn et al. 2015; Graffigna et al. 2015; Ngooi et al. 2017; Zill et al. 2013) as opposed to studies using factor analysis (Cunha et al. 2018; Moljord et al. 2015; Schmaderer et al. 2015; Skolasky et al. 2009). The earliest study to demonstrate that the PAM scale might be multidimensional was conducted among patients who underwent spine surgery (Skolasky et al. 2009). Three factors were found and labelled as 'beliefs', 'knowledge and confidence' and 'action and perseverance'. Another study among patients in a community mental health centre obtained two factors that were identified as 'believing active role as important/ responsibility', and 'knowledge and self-confidence' (Moljord et al. 2015).

The results in this study showed that these items could be grouped into three factors, thus supporting the statements that PAM may be multidimensional (Moljord et al. 2015; Skolasky et al. 2009). All items, except item number 5, have a factor loading of higher than 0.5 , which is considered significant (Hair et al. 2014). These items were categorised based on their highest loading value. The initial factor that emerged was identified as "confidence in performing preventive actions to maintain health" (items number 3, 4, 9-13). The first component reflects an important characteristic, which is being proactive and able to take steps to minimise problems related to health. This subscale signifies that a person should always be ready and able to anticipate potential problems, affirming that there is a positive association between performing preventive behaviours and health outcomes (Byrne et al. 2016; Marck et al. 2018). It also corresponds to the subdomains identified during the process of developing PAM (Hibbard et al. 2004).

The second factor highlighted the fundamental aspect of activation, which was "feeling responsible and in charge of own health" (items 1,2, and 5). This subscale emphasises two concepts in behavioural change, which are the internal locus of control and feeling of autonomy. These two elements are strongly connected to intrinsic motivation, a crucial factor for behavioural transformation (Ryan \& Deci 2000; Sundjoto 2017).

The third factor that was extracted from the analysis was "knowledge, ability to communicate and adherence to treatment" which consisted of items number 6, 7, and 8. Activated individuals possess adequate knowledge of the disease and have the ability to interact with healthcare providers (Hibbard et al. 2004). This interaction is essential towards building a collaborative relationship between patients and the healthcare team. It is an aspect of communicative literacy skills that should be acquired to make informed decisions (Nutbeam 2000). This study has shown several similarities with studies by Moljord et al. (2015) and Skolasky et al. (2009), in which the participants had one specific illness. Hence, the sample can be considered homogenous. The item in the first and third subscale in this study also showed some resemblance to the work by Skolasky et al. (2009).

The first two subscales demonstrated good internal consistency (Tavakol \& Dennick 2011), but for the third subscale, the value was 0.58 . This lower value could be because the items are measuring multiple attributes (i.e. knowledge, communication, and adherence), which are closely related to one another as demonstrated by the corrected item correlation in Table 5. Adherence seemed to be connected with knowledge and interactive skills, suggesting that it comes hand in hand with good understanding and communications (Jankowska-Polanska et al. 2016; Thompson \& Mccabe 2012). Although the alpha value of more than 0.7 is desirable, some researchers accepted a lower number of approximately 0.6 , particularly if the item is assessing knowledge or understanding (Berger \& Hänze 2015; Nehring et al. 2015).

All items have more than $50 \%$ of responses when 'agree' and 'strongly agree' categories were combined as similarly reported in previous studies (Graffigna et al. 2015; Ngooi et al. 2017; Packer et al. 2015). The highest percentage for these categories was item number 6 , which showed that the participants have no problem communicating their concern to their healthcare providers. This was probably because of the study location in an urban area, where there is easy access to healthcare facilities. Item number 12 has the lowest percentage for these categories, followed with items number 9 and 13 . Item number 12 may be difficult for participants with lower educational level as it requires the ability to solve problems. Likewise, the low responses for item number 9 might be due to their poor awareness of different diabetes treatments. Some participants may not be aware of insulin or other injections when oral hypoglycaemic agents are sufficient for their control. Furthermore, the lower percentage for item number 13 might be due to the age of the participants. Many were 60 years old and older, who might have difficulty to stay physically active.

The current work has also demonstrated that the ceiling effect was between 5.4 and $26.9 \%$, which was much lower than the values obtained by previous studies among the Western population (Graffigna et al. 2015; Packer et al. 2015). A ceiling effect of between 1 and 15\% is considered acceptable (Mchorney \& Tarlov 1995) and the value obtained in this study was relatively close. The differences in the ceiling effect suggested a possibility that the way people in Malaysia respond to the survey may not be similar to other societies and this demands further investigation. This observation also concurs with an earlier report stating that people in East Asia tend to be moderate when giving their responses (Hamamura et al. 2008). 


\section{LIMITATIONS AND STRENGTHS}

The present study has several limitations. The data were collected at one primary healthcare clinic situated in an urban area, and thus, the results cannot be generalised. Nevertheless, there was no missing data in the PAM items as we had excluded them from the analysis. The number of samples was also insufficient to perform Confirmatory Factor Analysis.

\section{CONCLUSION AND RECOMMENDATION}

The Malay PAM scale is a reliable and valid tool to assess patient activation for diabetes care. The findings suggested that it might be possible to have three dimensions in the Malay version of PAM scale. It is hoped that this study can contribute towards better refinement in the meaning of patient activation in the local setting. Further investigation is recommended to understand the structure of PAM scale as its properties may differ according to the patients' context, particularly the nature of medical condition involved, educational level and health culture.

\section{IMPLICATIONS FOR CLINICAL PRACTICE}

In the context of diabetes care, PAM scale is a potential tool in detecting self-management needs, patients' readiness and their competency level. Apart from measuring their activation level and overall PAM score, it is beneficial to look into the total score of each subscale. By assessing these subscales, it would be possible to identify areas that need improvement. It would also help healthcare providers to be more detailed in responding to patients' needs and in designing specific intervention programmes to assist patients in becoming active health managers.

\section{ACKNOWLEDGEMENTS}

The authors would like to express their gratitude to Profesor Dr. Tong Seng Fah, Dr Saharuddin Ahmad and Dr Anita Jain Devi for their expert opinion. They would also like to thank Dr. Nuraida Baharuddin, Dr. Hana Azhari, Miss Dewi Sri and Renetha for their contribution in the translation process. The authors would also like to acknowledge the clinic staffs and patients' for their assistance in this study. The authors would like to declare that there is no conflict of interest in this study. This validation study is part of a research project entitled 'Patient Activation Intervention for diabetes care at primary care setting' and was approved by the Medical Research \& Ethical Committee of the Faculty of Medicine, Universiti Kebangsaan Malaysia Medical Centre (reference number: 2018-235). This study received fund from the Faculty of Medicine, Universiti Kebangsaan Malaysia.

\section{REFERENCES}

Ahn, Y.H., Yi, C.H., Ham, O.K. \& Kim, B.J. 2015. Psychometric properties of the korean version of the "patient activation measure 13" (PAM13-K) in patients with osteoarthritis. Evaluation \& the Health Professions 38(2): 255-264.

American Diabetes Association (ADA). 2017. Standards of medical care in diabetes 2017. The Journal of Clinical and Applied Research and Education 40: 1-142.

Berger, R. \& Hänze, M. 2015. International journal of science impact of expert teaching quality on novice academic performance in the jigsaw cooperative learning method. International Journal of Science Education 37(2): 294-320.

Bos-touwen, I., Schuurmans, M., Monninkhof, E., Korpershoek, Y., Spruit-Bentvelzen, L., Ertugrul-van der Graaf, I., DeWit, N. \& Trappenburg, J. 2015. Patient and disease characteristics associated with activation for selfmanagement in patients with diabetes, chronic obstructive pulmonary disease, chronic heart failure and chronic renal disease: A cross-sectional survey study. PloS ONE 10(5): e0126400.

Byrne, D.W., Rolando, L.A., Aliyu, M.H., Mcgown, P.W., Connor, L.R., Awalt, B.M., Holmes, M.C., Wang, L. \& Yarbrough, M.I. 2016. Modifiable healthy lifestyle behaviors 10year health outcomes from a health promotion program. American Journal of Preventive Medicine 51(6): 1027-1037.

Cheng, C., Cheung, S.F., Chio, J. \& Chan, M. 2013. Cultural meaning of perceived control: A meta-analysis of locus of control and psychological symptoms across 18 cultural regions. Psychological Bulletin 139(1): 152-188.

Chrvala, C.A., Sherr, D. \& Lipman, R.D. 2016. Diabetes selfmanagement education for adults with type 2 diabetes mellitus: A systematic review of the effect on glycemic control. Patient Education and Counseling 99(6): 926-943.

Costello, A. \& Osborne, J. 2005. Best practices in exploratory factor analysis: Four recommendations for getting the most from your analysis. Practical Asessment, Research and Evaluation 10(7): 1-9.

Cunha, C., Nepomuceno, E., Manzato, R., da Cunha, D. \& Dantas, R. 2018. Cultural adaptation and validation of the brazilian version of the patient activation measure-22 items. Revista Brasileira de Enfermagem 71(4): 1891-1898.

Graffigna, G., Barello, S., Bonanomi, A., Lozza, E. \& Hibbard, J. 2015. Measuring patient activation in Italy: Translation, adaptation and validation of the Italian version of the patient activation measure 13 (PAM13-I). BMC Medical Informatics and Decision Making 15(109): 1-13.

Greene, J., Hibbard, J.H., Sacks, R., Overton, V. \& Parrotta, C.D. 2015. When patient activation levels change, health outcomes and costs change, too. Health Affairs 34(3): 431437.

Hair, J.F., Black, W.C., Babin, B.J. \& Anderson, R.E. 2014. Multivariate Data Analysis. London: Pearson Education Limited.

Hamamura, T., Heine, S. \& Paulhus, D. 2008. Cultural differences in response styles: The role of dialectical thinking. Personality and Individual Differences 44(4): 932-942.

Hibbard, J.H. \& Greene, J. 2013. What the evidence shows about patient activation: Better health outcomes and care 
experiences; fewer data on costs. Health Affairs 32(2): 207-214.

Hibbard, J.H., Mahoney, E.R., Stockard, J. \& Tusler, M. 2005. Development and testing of a short form of the patient activation measure. Health Services Research 40(6 Part I): 1918-1930.

Hibbard, J.H., Stockard, J., Mahoney, E.R. \& Tusler, M. 2004. Development of the Patient Activation Measure (PAM): Conceptualizing and measuring activation in patients and consumers. Health Services Research 39(4p1): 1005-1026.

Holman, H. \& Lorig, K. 2004. Patient self-management: A key to effectiveness and efficiency in care of chronic disease. Public Health Reports 119(3): 239-243.

Insignia Health Institute. 2009. Preventing \& Addressing Unreliable PAM.

Institute for Public Health (IPH). 2015. National Health and Morbidity Survey 2015 (NHMS 2015). Vol. Ii: Noncommunicable diseases, risk factors \& other health problems. Putrajaya: Ministry of Health Malaysia.

Jankowska-Polanska, B., Uchmanowicz, I., Dudek, K. \& Mazur, G. 2016. Relationship between patients' knowledge and medication adherence among patients with hypertension. Patient Preference and Adherence 10: 2437-2447.

Laranjo, L., Dias, V., Nunes, C., Paiva, D. \& Mahoney, B. 2018. Translation and validation of the patient activation measure in portuguese people with type 2 diabetes mellitus. Acta Medica Portuguesa 31(7-8): 382-390.

Lucas, A., Murray, E. \& Kinra, S. 2013. Health beliefs of UK South Asians related to lifestyle diseases: A review of qualitative literature. Journal of Obesity 1: 827674.

Mafauzy, M., Hussein, Z. \& Chan, S. 2011. The status of diabetes control in Malaysia: Results of DiabCare 2008. Medical Journal of Malaysia 66(3): 175-181.

Marck, C., Livera, A., Brown, C., Neate, S., Taylor, L., Weiland, T., Hadgkiss, E. \& Jelinek, G.A. 2018. Health outcomes and adherence to a healthy lifestyle after a multimodal intervention in people with multiple sclerosis: three year follow-up. PLoS ONE 13(5): e0197759.

Mccabe, P.J., Stuart-mullen, L., Mcleod, C., Byrne, T., Schmidt, M., Branda, M. \& Griffin, J. 2018. Patient activation for self-management is associated with health status in patients with atrial fibrillation. Patient Preference and Adherence 12: 1907-1916.

McHorney, C. \& Tarlov, A. 1995. Individual-patient monitoring in clinical practice: Are available health status surveys adequate? Quality of Life Research 4(4): 293-307.

Moljord, I., Lara-Cabrera, M., Perestelo-Pérez, L., RiveroSantana, A., Eriksen, L. \& Linaker, O. 2015. Psychometric properties of the patient activation measure-13 among outpatients waiting for mental health treatment: A validation study in Norway. Patient Education and Counseling 98(11): 1410-1417.

Nehring, A., Nowak, K., Belzen, A. \& Tiemann, R. 2015. Predicting students' skills in the context of scientific inquiry with cognitive, motivational, and sociodemographic variables. International Journal of Science Education 37(9): 1343-1363.

Ngooi, B., Packer, T., Warner, G., Kephart, G., Koh, K., Wong, R. \& Lim, S. 2017. Validation of the Patient Activation
Measure (PAM-13) among adults with cardiac conditions in Singapore. Quality of Life Research 26(4): 1-10.

Nutbeam, D. 2000. Health literacy as a public health goal: A challenge for contemporary health education and communication strategies into the 21 st century. Health Promotion International 15(3): 259-267.

Packer, T.L., Kephart, G., Ghahari, S., Audulv, A., Versnel, J. \& Warner, G. 2015. The patient activation measure: A validation study in a neurological population. Quality of Life Research 24(7): 1587-1596.

Patel, N., Chew-Graham, C., Bundy, C., Kennedy, A., Blickem, C. \& Reeves, D. 2015. Illness beliefs and the sociocultural context of diabetes self-management in British South Asians: A mixed methods study. BMC Family Practice 16(1): 58

Perfetti, A. 2018. Fate and the clinic: A multidisciplinary consideration of fatalism in health behaviour. Medical Humanities 44(1): 59-62.

Quek, D. 2014. The Malaysian Health Care System: A Review. Kuala Lumpur: Malaysian Medical Association.

Rademakers, J., Nijman, J., van der Hoek, L., Heijmans, M. \& Rijken, M. 2012. Measuring patient activation in the Netherlands: Translation and validation of the American short form Patient Activation Measure (PAM13). BMC Public Health 12(1): 577.

Remmers, C., Hibbard, J., Mosen, D.M., Wagenfield, M., Hoye, R.E. \& Jones, C. 2009. Is patients activation associates with the future health outcomes and healthcare utilization among patients with diabetes? The Journal of Ambulatory Care Management 4(4): 1-8.

Roberts, N.J., Kidd, L., Dougall, N., Patel, I.S., Mcnarry, S. \& Nixon, C. 2016. Patient education and counseling measuring patient activation: The utility of the patient activation measure within a UK context - results from four exemplar studies and potential future applications. United Kingdom: Patient Education and Counseling.

Ryan, R. \& Deci, E. 2000. Self-determination theory and the facilitation of intrinsic motivation, social development, and well-being. The American Psychologist 55(1): 68-78

Sacks, R., Greene, J., Hibbard, J., Overton, V. \& Parrotta, C. 2017. Patient education and counseling does patient activation predict the course of type 2 diabetes? A longitudinal study. Patient Education and Counseling (2016): 1-8.

Schmaderer, M., Pozehl, B., Hertzog, M. \& Zimmerman, L. 2015. Psychometric properties of the patient activation measure in multimorbid hospitalized patients. Journal of Nursing Measurement 23(3): 128-141.

Shah, V., Carroll, C., Mals, R., Ghahate, D., Bobelu, J., Sandy, P., Colleran, K., Schrader, R., Faber, T. \& Burge, M.R. 2015. A home-based educational intervention improves patient activation measures and diabetes health indicators among Zuni Indians. PLoS ONE 10(5): e0125820.

Shively, M., Gardetto, N., Kodiath, M., Kelly, A., Smith, T., Stepnowsky, C., Maynard, C. \& Larson, C. 2013. Effect of patient activation on self-management in patients with heart failure. The Journal of Cardiovascular Nursing 28(1): 20-34.

Shrivastava, S.R., Shrivastava, P.S. \& Ramasamy, J. 2013. Role of self-care in management of diabetes mellitus. Journal of Diabetes \& Metabolic Disorders 12(14): 1-5. 
Skolasky, R., Mackenzie, E., Riley, L. \& Stephen, T. 2009. Psychometric properties of the Patient Activation Measure among individuals presenting for elective lumbar spine surgery. Quality of Life Research 18(10): 1357-1366.

Sundjoto, S. 2017. The role of internal locus of control on intrinsic motivation and employee performance of ceramic company in East Java Sundjoto. IOSR Journal of Business and Management 19(7): 29-35.

Tavakol, M. \& Dennick, R. 2011. Making sense of Cronbach's alpha. International Journal of Medical Education 2: 53-55.

Thompson, L. \& Mccabe, R. 2012. The effect of clinician-patient alliance and communication on treatment adherence in mental health care: A systematic review. BMC Psychiatry 12(1): 87.

World Health Organization (WHO). 2016. Global Report on Diabetes. Geneva: WHO Press.

World Health Organization (WHO). 2014. Global Status Report on Noncommunicable Diseases. Geneva: WHO Press.

Yeoh, S., Tam, C., Wong, C. \& Bonn, G. 2017. Examining depressive symptoms and their predictors in Malaysia: Stress, locus of control, and occupation. Frontiers in Psychology 8: 1411.

Zill, J., Dwinger, S., Kriston, L., Rohenkohl, A., Härter, M. \& Dirmaier, J. 2013. Psychometric evaluation of the German version of the patient activation measure (PAM13). BMC Public Health 13(1): 1027.

Zimbudzi, E., Lo, C., Ranasinha, S., Kerr, P.G., Polkinghorne, K.R., Teede, H., Usherwood, T., Walker, R.G., Johnson, G., Fulcher, G. \& Zoungas, S. 2017. The association between patient activation and self-care practices: A cross-sectional study of an Australian population with comorbid diabetes and chronic kidney disease. Health Expectations 20: 1375-1384.
Syahnaz Mohd Hashim \& Idayu Badilla Idris*

Department of Community Health

Universiti Kebangsaan Malaysia Medical Centre 56000 Kuala Lumpur, Federal Territory

Malaysia

Syahnaz Mohd Hashim

Department of Family Medicine

Universiti Kebangsaan Malaysia Medical Centre 56000 Kuala Lumpur, Federal Territory

Malaysia

Shalisah Sharip

Department of Psychiatry

Universiti Kebangsaan Malaysia Medical Centre

56000 Kuala Lumpur, Federal Territory

Malaysia

Rafidah Bahari

Department of Psychiatry

Cyberjaya University College of Medical Sciences 63000 Cyberjaya, Selangor Darul Ehsan

Malaysia

Nasrin Jahan

Freelance Public Health Physician

Dhaka

Bangladesh

*Corresponding author; email: idayubadilla.idris@gmail.com

Received: 30 April 2019

Accepted: 18 April 2020 